\title{
Specification of Zwitterionic or Non-Zwitterionic Structures of Amphoteric Compounds by Using Ionic Liquids
}

\author{
Leila Sheikhian, ${ }^{1, \star}$ Morteza Akhond ${ }^{2}$ and Ghodratollah Absalan ${ }^{2}$ \\ ${ }^{1}$ Department of Chemistry, Kazerun Branch, Islamic Azad University, Kazerun, Iran \\ ${ }^{2}$ Department of Chemistry, College of Sciences, Shiraz University, Shiraz, 71454, Iran \\ *Corresponding author: E-mail: fsheikhian59@gmail.com, sheikhian@kau.ac.ir \\ Tel.: +98 7142243930-9, Fax: +98 7142230508
}

Received: 06-28-2019

\begin{abstract}
Some imidazolium-based ionic liquids were used to determine zwitterionic or non-zwitterionic structures of glycine and p-amino benzoic acid, as model amphoteric compounds, in their corresponding isoelectric point. To do this, the partitioning behaviors of both compounds between the ionic liquid and aqueous phase at different $\mathrm{pH}$ values were investigated. The results revealed that due to having different $\mathrm{pH}$-dependent chemical structures, each compound showed different partitioning behavior. This observation was considered as a basis for introducing a green technique for understanding the real chemical structures (species), i.e. zwitterionic or non-zwitterionic structures of amphoteric compounds such as amino acids in the aqueous solutions. This study revealed the existence of a non-zwitterionic (neutral) structure for p-amino benzoic acid and a zwitterionic structure for glycine in their corresponding isoelectric points.
\end{abstract}

Keywords: p-Amino benzoic acid; Glycine; Ionic liquid; Partition coefficient; Zwitterion

\section{Introduction}

Charge characterization and speciation of amino acids is of interest not only in biological sciences for better understanding of the metabolic processes in tissue membranes but also in analytical chemistry for improving and designing new separation and measurement procedures. Generally, knowing the chemical forms, including the charged structures, of a compound as it really exists in a sample would help revealing its true impact on human or the environment. Speciation analysis plays a unique role in studies of biogeochemical cycles of chemical compound, determination of toxicity as well as ecotoxicity of selected elements, quality control of food products, control of medicines and pharmaceutical products, technological process control, and clinical analysis. For instance, zwitterions, used widely in chemical, biological and medicinal fields, show distinct physicochemical properties relative to ordinary ampholytes, which largely decide their bioavailability and biological activities. ${ }^{1}$ Many studies including computational protocols have been done about charge characterization of peptides and proteins (to interpret their mass spectrometry data) ${ }^{2}$ as well as amino acids in gas phase..$^{3-8}$ However, few studies about the charged structures of amino acids in aqueous phase are available for checking the studies reported by many authors. In 1916, Adams showed that an amino acid might possess a zwitterionic structure, i.e. ${ }^{+} \mathrm{NH}_{3}-\mathrm{R}-\mathrm{COO}^{-}$, rather than a non-zwitterionic classical structure, i.e. $\mathrm{NH}_{2}-\mathrm{R}-\mathrm{COOH}$, in aqueous solutions. ${ }^{9}$ However, opposite ideas also were reported. ${ }^{10}$ In this regard, in 1930, Harris was able to provide direct evidence through doing many titrations and experiments to show that an amino acid molecule does possess, in preponderant proportion, a zwitterionic rather than a non-zwitterionic classical structure. ${ }^{11}$ In a recent study, amino acids were considered as neutral species, ${ }^{12}$ while previous studies showed that they can exist in zwitterionic form. So it is necessary to investigate the real amino acid species in aqueous solutions.

Klotz and Gruen performed many experiments and compared the ionization constants of the amino groups in $p$-amino benzoic acid (PABA) and its esteric compounds to reveal that PABA is primarily neutral (i.e. free of any charge) in its isoelectric point ( $\mathrm{pI}=3.68) .{ }^{13}$ Other studies 
showed that PABA exists in neutral and not in zwitterionic form in its isoelectric point in aqueous solutions. ${ }^{14,15}$ Yet to have further evidence, alternative procedures are required for confirming the above mentioned assumptions such as that presented in this article.

Room temperature ionic liquids (RTILs) ${ }^{16-18}$ are known as green solvents and applied in different chemical scopes, such as electrochemistry, ${ }^{19}$ batteries and fuel cells investigations, ${ }^{20,21}$ chemicals synthesis, ${ }^{22}$ catalytic processes ${ }^{23}$ and separation sciences. ${ }^{24-26}$ Also, interactions of chemical compounds with ILs can be considered as models of bio-membranes for studying the membrane permeability or structure-activity relationships. It has been reported that the distribution coefficients of ionized forms of solutes in ILs are between one and three orders of magnitude lower than those of the molecular substances. ${ }^{27,28}$ So, studying the partitioning behaviors of different compounds, specifically the amphoteric substances, in IL/ $\mathrm{H}_{2} \mathrm{O}$ system would be a way to obtain information about their different charged species including the zwitterions.

In this work, a simple and efficient methodology is introduced to characterize zwitterionic or non-zwitterionic structure of glycine, as a model amino acid, as well as that of PABA in the isoelectric points by studying their partitioning behaviors between aqueous and ionic liquid phases. The ionic liquids used in this study have imidazolium-based chemical structures: 1-butyl-3-methylimidazolium hexaflorophosphate, $\left[\mathrm{C}_{4} \mathrm{mim}\right]\left[\mathrm{PF}_{6}\right] ;$ 1-octyl-3-methylimidazolium tetrafloroborate, $\left[\mathrm{C}_{8} \mathrm{mim}\right]\left[\mathrm{BF}_{4}\right]$, and 1-octyl-3-methylimidazolium hexaflorophosphate, $\left[\mathrm{C}_{8} \mathrm{mim}\right]\left[\mathrm{PF}_{6}\right]$.

\section{Experimental}

\section{1. Instrument}

The UV-Vis absorption spectra were recorded against the solvent blank at room temperature, using Ultrospec 4000 spectrophotometer (Pharmacia Biotech). A Metrohm $780 \mathrm{pH}$-meter was applied for $\mathrm{pH}$ measurements. The NMR spectra were recorded using a Brucker-Advanced DPX/250 $\left({ }^{1} \mathrm{H}\right.$ NMR $250 \mathrm{MHz}$ and ${ }^{13} \mathrm{C}$ NMR $62.9 \mathrm{MHz}$ ) spectrophotometer.

\section{2. Reagents}

Ammonium hexafluorophosphate and sodium tetrafluoroborate were purchased from Fluka; 1-bromobutane, 1-bromooctane, 1-methylimidazolium, glycine, $p$-amino benzoic acid (PABA), ninhydrin, and hydrindantin dihydrate were purchased from Merck Chemical Company with the highest available purity and were used without further purification. The ionic liquids (Table1): 1-butyl-3-methylimidazolium hexaflorophosphate, $\left[\mathrm{C}_{4} \mathrm{mim}\right]\left[\mathrm{PF}_{6}\right]$; 1-octyl-3-methylimidazolium tetrafloroborate, $\left[\mathrm{C}_{8} \mathrm{mim}\right]\left[\mathrm{BF}_{4}\right]$ and 1-octyl-3-methylimidazolium hexaflorophosphate, $\left[\mathrm{C}_{8} \mathrm{mim}\right]\left[\mathrm{PF}_{6}\right]$, were synthesized as described in literature ${ }^{29,30}$ and their chemical structures were verified by using NMR spectroscopy. The obtained NMR spectra of ILs were in good agreement with the previously reported spectra ${ }^{28,29,31,32}$ and no traces of impurities were observed. Distilled deionized water was used throughout this work.

\section{3. Procedure}

Individual aqueous solutions containing $1.0 \times 10^{-3}$ mol L $\mathrm{L}^{-1}$ of either glycine or PABA (each with a volume of $500 \mu \mathrm{l}$ ) were brought into contact with $50 \mu \mathrm{l}$ of IL at room temperature in a stoppered glass test tube. The ionic strengths of aqueous solutions were kept constant using the $0.10 \mathrm{~mol} \mathrm{~L}^{-1} \mathrm{KCl}$ solution for all $\mathrm{pH}$ values. Each system was vigorously stirred with a magnetic stirrer for 30 minutes and then both phases were carefully separated using a centrifugation device. The partition coefficients of both glycine and PABA between the IL phase and aqueous solution (IL/ $\mathrm{H}_{2} \mathrm{O}$ system) were calculated according to the following equation: $K_{\mathrm{IL} / \mathrm{W}}=\left[\left(C_{\mathrm{i}}-C_{\mathrm{f}}\right) V_{\mathrm{aq}}\right] /\left[C_{\mathrm{f}} V_{\mathrm{IL}}\right]$ where $C_{\mathrm{i}}$ and $C_{f}$, respectively, refer to the initial and final concentrations of each compound in aqueous phase; $V_{\text {aq }}$ and $V_{\text {IL }}$ refer to the aqueous and IL phase volumes, respectively. Final concentration of PABA in the aqueous phase was directly determined by using UV-Vis spectrophotometry. Final concentration of glycine in aqueous phase was determined by ninhydrine method. ${ }^{33}$ Generally, in this method the glycine solution is mixed with a solution prepared by dissolving $2.0 \mathrm{~g}$ ninhydrin and $0.30 \mathrm{~g}$ hydrindantin in 75 $\mathrm{mL}$ DMSO and $25 \mathrm{ml}$ of sodium acetate buffer in $\mathrm{pH} 6.4$. The mixture is heated up in a boiling water bath for a period of 5 minutes. Afterward, it is immediately cooled in an ice-bath. The absorbance of the mixture is measured with spectrophotometer at $575 \mathrm{~nm}$.

It is stressed that each point presented on charts in Figures 1 and 2 is the average of triplicate measurement.

\section{Results and Discussion}

\section{1. Partitioning of Glycine into Imidazolium-Based ILs}

As it is shown in Figure 1, comparison at different $\mathrm{pHs}$, partition coefficient of glycine is relatively high in the $\mathrm{pH}$ region where its cationic $\left(\mathrm{A}^{+}\right)$and anionic $\left(\mathrm{A}^{-}\right)$species (Table 1 ) are dominant. However, the $K$ value for distribution of glycine between water and $\left[\mathrm{C}_{8} \mathrm{mim}\right]\left[\mathrm{BF}_{4}\right]$ is higher (up to $K=2.0$ ) at low $\mathrm{pH}$.

Electrostatic interactions of $\mathrm{A}^{+}$and $\mathrm{A}^{-}$, respectively, with the anionic and cationic parts of the studied ILs are responsible for showing this behavior. ${ }^{30,34}$ Partition coefficient of the species with net zero-charge (i.e, either a zwitterionic species with both positive and negative charges in 


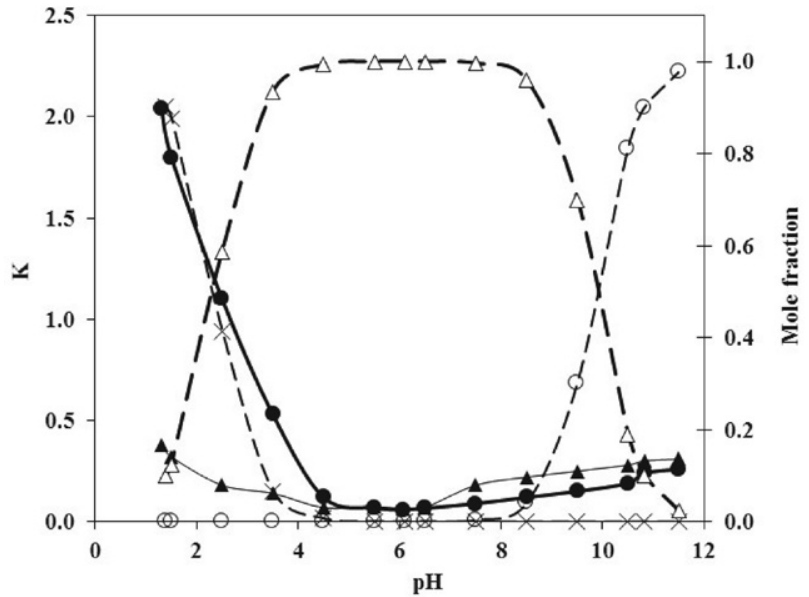

Figure 1. Partition coefficients $(K)$ of glycine between water and different ionic liquids: $(\boldsymbol{\Delta}),\left[\mathrm{C}_{4} \mathrm{mim}\right]\left[\mathrm{PF}_{6}\right] ;(\bullet),\left[\mathrm{C}_{8} \mathrm{mim}\right]\left[\mathrm{BF}_{4}\right]$. Mole fraction of various chemical forms of glycine in different $\mathrm{pH}$ values: $(x)$, cationic form $\left(\mathrm{A}^{+}\right) ;(\Delta)$, zwitterionic form $\left(\mathrm{A}^{ \pm}\right)$; $(\mathrm{O})$, anionic form $\left(\mathrm{A}^{-}\right)$.

Table 1. Zwitterionic, cationic and anionic chemical structures of Glycine pK1 $=2.35, \mathrm{pK} 2=9.77, \mathrm{pI}=6.06$ ) and $\mathrm{p}$-amino benzoic acid, PABA, $(\mathrm{pK} 1=2.49, \mathrm{pK} 2=4.87, \mathrm{pI}=3.68)$.

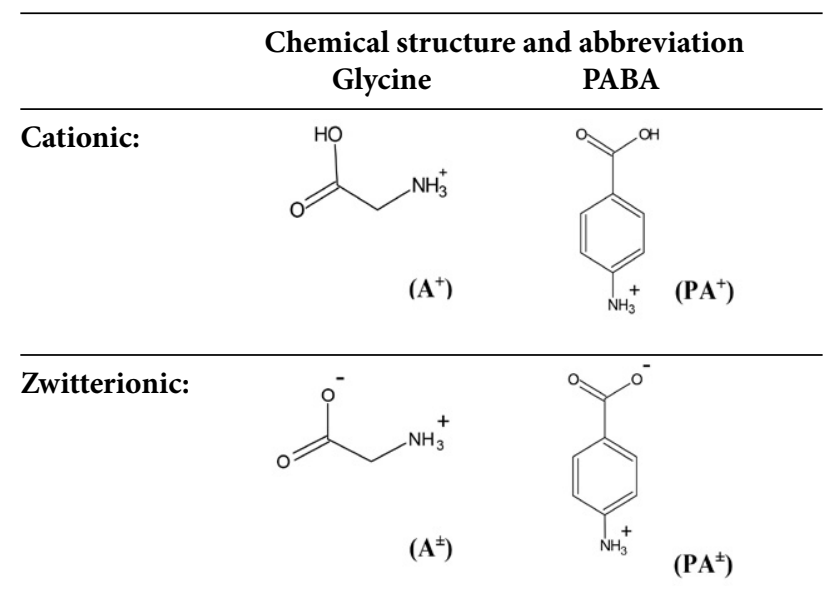

Neutral:

$$
\mathrm{NH}_{0}^{\mathrm{OH}}
$$

(A)

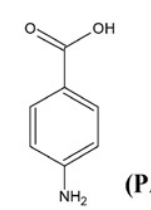

(PA)

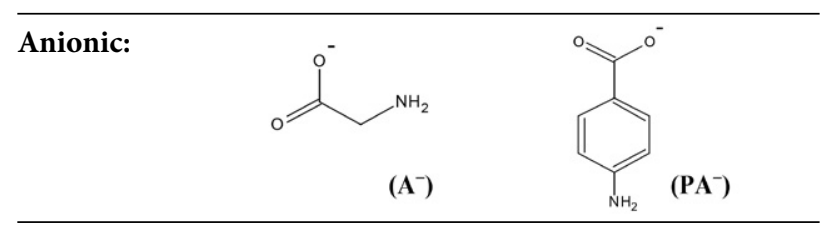

one molecule, or a neutral species that does not have any charge) of glycine $\left(\mathrm{A}^{ \pm}\right)$is the lowest as a consequence of diminishing of its electrostatic interactions with IL due to the presence of a net zero-charge on the molecule. Moreover, in spite of simultaneous presence of two ionized groups, i.e. ${ }^{+} \mathrm{NH}_{3}$ and $\mathrm{COO}^{-}$, the hydrophobicity of glycine molecule decreases so that a lower partition coefficient of its zwitterionic form, $\mathrm{A}^{ \pm}$, in the $\mathrm{pH}$ range $4.0-8.0$ is achieved. This behavior showed that the net zero-charge of glycine species at its isoelectric point ( $\mathrm{pH} \mathrm{6.06)} \mathrm{has} \mathrm{a} \mathrm{zwitterion-}$ ic (not neutral) structure; because of this, hydrophobicity and consequently its extraction into IL phase is the lowest.

These results show that the number of ionized groups in a molecule is a determining factor for its extraction into the IL phase. Since glycine has two ionized groups $\left({ }^{+} \mathrm{NH}_{3}\right.$ and $\mathrm{COO}^{-}$) in its isoelectric point, but in acidic or basic conditions has only one of these ionized groups (i.e. ${ }^{+} \mathrm{NH}_{3}$ or $\mathrm{COO}^{-}$, respectively, in acidic and basic solutions), partitioning of its zwitterionic form into IL phase is not better compared to its other two forms. These results confirm that glycine has a zwitterionic structure in its isoelectric point which was also already verified by Harris. ${ }^{11}$

If glycine is neutral (instead of being zwitterion) in its isoelectric point, then it will be expected to have a higher partition coefficient due to a more hydrophobic character in comparison to its both cationic $\left(\mathrm{A}^{+}\right)$and anionic forms $\left(\mathrm{A}^{-}\right)$.

It is noticeable that charge densities of the ionic constituents of IL phase may affect its extracting ability when it interacts with different forms of an amino acid such as glycine. For instance, the electrostatic interaction of cationic form of glycine $\left(\mathrm{A}^{+}\right)$with the anionic part of an IL, i.e. $\mathrm{BF}_{4}{ }^{-}$or $\mathrm{PF}_{6}{ }^{-}$, depends on the value of the charge density of these ions. Table 2 provides the calculated charge densities of constituent ions of the ILs used in this study. ${ }^{34}$ As it is shown in this table, the charge density of $\mathrm{BF}_{4}^{-}$is higher than $\mathrm{PF}_{6}{ }^{-}$; also quantum chemical calculations indicated that the effective negative charge in $\mathrm{BF}_{4}{ }^{-}$is much higher than in $\mathrm{PF}_{6}{ }^{-} .35$ Therefore, stronger electrostatic interaction between the cationic form of glycine and $\mathrm{BF}_{4}^{-}$, and consequently a higher extraction of $\mathrm{A}^{+}$into $\mathrm{BF}_{4}{ }^{-}$-based ILs, is expected as demonstrated in Figure 1.

It has been reported that the presence of water in ionic liquids may have important implications on the properties of room temperature ILs as solvents, such as conductivity, viscosity and diffusivity. ${ }^{36}$ The water content of ILs is an important parameter that must be taken into consideration for evaluating the different extraction behaviors of ILs. But, before continuing the following discussion, it should be mentioned that in this text, the water contents of ILs refers to the amount of water that ILs are capable to absorb during their contact time with aqueous phase for a duration of $30 \mathrm{~min}$ in all the experiments. In this contact, the ion-pair association between cationic and anionic constituents of an IL is partially disrupted in the presence of water due to the development of $\mathrm{H}$-bonding between water and the anionic part of the IL. For imidazolium-based ILs, it has been reported ${ }^{37}$ that water molecules (in the content range of $0.2-1.0$ mole water per liter of IL) are mostly in free (not self-associated) state but could bind to the anionic constituent, i.e. $\mathrm{PF}_{6}{ }^{-}$or $\mathrm{BF}_{4}{ }^{-}$, of the IL. Furthermore, the 
bulky cations of ILs containing long alkyl chains can organize water molecules around themselves. These types of ILs undergo hydrophobic hydration in water that is usually known as the formation of more oriented and rigid structures of water surrounding the ILs. ${ }^{38,39}$ In this situation, the interaction between anionic and cationic constituents of the IL decreases; however, the electrostatic interactions between cationic form of glycine $\left(\mathrm{A}^{+}\right)$and anionic part of IL enhances. Therefore, the partition coefficients of glycine in the $\mathrm{pH}$ values that exists in its cationic form directly depend on the water content of IL.

According to literature, ${ }^{40}$ the water contents of ILs decrease in the order of $\left[\mathrm{C}_{8} \mathrm{mim}\right]\left[\mathrm{BF}_{4}\right]>\left[\mathrm{C}_{4} \mathrm{mim}\right]\left[\mathrm{PF}_{6}\right]$ $>\left[\mathrm{C}_{8} \mathrm{mim}\right]\left[\mathrm{PF}_{6}\right]$, which exactly follows the same order found for ILs in the extraction of cationic form of glycine (Figure 1). It is to be noticed that the partition coefficient of glycine, when $\left[\mathrm{C}_{8} \mathrm{mim}\right]\left[\mathrm{PF}_{6}\right]$ was used as IL, was so low that it could not be shown in Figure 1.

In brief, both water contents of ILs as well as charge density of their anionic parts make cationic form of glycine to be extracted into IL phase in an order of $\left[\mathrm{C}_{8} \mathrm{mim}\right]$ $\left[\mathrm{BF}_{4}\right]>\left[\mathrm{C}_{4} \mathrm{mim}\right]\left[\mathrm{PF}_{6}\right]>\left[\mathrm{C}_{8} \mathrm{mim}\right]\left[\mathrm{PF}_{6}\right]$, (Figure 1 ).

At $\mathrm{pHs} \geq 7$ (Figure 1) where anionic form of glycine $\left(\mathrm{A}^{-}\right)$is dominant, water content and charge density of the cationic form of IL (i.e. the imidazolium ion) could be examined as the possible driving forces for extraction of $\mathrm{A}^{-}$ into the IL phase. It should be noticed again that the partition coefficients, when $\left[\mathrm{C}_{8} \mathrm{mim}\right]\left[\mathrm{PF}_{6}\right]$ was used as IL, were so low that they are not shown in this figure. However, the order of ILs for partitioning of $\mathrm{A}^{-}$could be considered as $\left[\mathrm{C}_{4} \mathrm{mim}\right]\left[\mathrm{PF}_{6}\right]>\left[\mathrm{C}_{8} \mathrm{mim}\right]\left[\mathrm{BF}_{4}\right]>\left[\mathrm{C}_{8} \mathrm{mim}\right]\left[\mathrm{PF}_{6}\right]$ based on data shown in Figure 1. This is in agreement with the order of charge densities of cationic parts of ILs (Table 2). The $\left[\mathrm{C}_{4} \mathrm{mim}\right]\left[\mathrm{PF}_{6}\right]$, with both higher charge density in its cationic part and lower water content than $\left[\mathrm{C}_{8} \mathrm{mim}\right]\left[\mathrm{BF}_{4}\right]$, has provided higher partitioning for the anionic forms of glycine. This observation shows that charge density of cationic part of ILs is favorable for extraction of glycine. It seems that the extraction of $\mathrm{A}^{-}$is favored by the water content of the IL when ILs have similar cationic constituents but different water contents.

Extraction of $\mathrm{A}^{-}$into $\left[\mathrm{C}_{8} \mathrm{mim}\right]\left[\mathrm{BF}_{4}\right]$, with a higher water content, was found to be higher than that of $\left[\mathrm{C}_{8} \mathrm{mim}\right]$ $\left[\mathrm{PF}_{6}\right]$, which has the least water content. The results obtained for partition coefficients of $\mathrm{A}^{-}$in different ILs reveal that both charge density of the cationic part of IL and its water content are responsible for the extraction of $\mathrm{A}^{-}$but they may counteract. As it is shown in Figure 1, the differences in the values of the partition coefficients of $\mathrm{A}^{-}$in different ILs are not as remarkable as those observed for $\mathrm{A}^{+}$ in different ILs. It should be mentioned that $\left[\mathrm{C}_{4} \mathrm{mim}\right]\left[\mathrm{BF}_{4}\right]$ could not be studied in this work as it is soluble in water.

The order of ILs for partitioning of zwitterionic form of glycine is as follows: $\left[\mathrm{C}_{8} \mathrm{mim}\right]\left[\mathrm{BF}_{4}\right]>\left[\mathrm{C}_{4} \mathrm{mim}\right]\left[\mathrm{PF}_{6}\right]>$ $\left[\mathrm{C}_{8} \mathrm{mim}\right]\left[\mathrm{PF}_{6}\right]$. Polarity and water content of ILs are concluded to be the effective parameters that could explain the
Table 2. Chemical structures and charge densities of ionic parts of the ionic liquids used

\begin{tabular}{cc}
\hline Ion & Charge density $\left(\mathbf{e} / \AA^{3}\right)$ \\
\hline & \\
$1-\mathrm{Butyl}-3-$ methylimidazolium, & \\
\hline $\mathrm{C}_{4} \mathrm{mim}^{+}$ & 0.00541 \\
& \\
$\mathrm{PF}_{6}^{-}$ & 0.00306 \\
$\mathrm{BF}_{4}^{-}$ & 0.00941 \\
\hline
\end{tabular}

above observation. Partition coefficient is more dependent on the charge density of the ionic components of ILs than on its water content (which in a way reflects the polarity of IL). As $\left[\mathrm{C}_{8} \mathrm{mim}\right]\left[\mathrm{PF}_{6}\right]$ is a least polar IL with least water content, it is expected that glycine as a polar compound $(\log K$ in octanol is around -3 ) would have the smallest $K$ in this IL.

\section{2. Partitioning of p-amino Benzoic Acid Into Imidazolium-Based ILs}

Partitioning behavior of PABA between water and imidazolium-based IL phases, at different aqueous $\mathrm{pH}$ values, was investigated. As shown in Figure 2, partition coefficient of PABA was the highest at its isoelectric point showing that the hydrophobicity of PABA could be the reason for its higher extraction in the IL phase. This consequently proves that PABA exists in a neutral rather than in a zwitterionic form at its isoelectric point. At $\mathrm{pH}$ values higher or lower than the isoelectric $\mathrm{pH}$, ionic forms of PABA $\left(\mathrm{PA}^{-}\right.$and $\left.\mathrm{PA}^{+}\right)$, with lower hydrophobicity than its neutral form (PA), have lower tendency for transporting into the IL phase. Therefore, the electrostatic interactions of $\mathrm{PA}^{-}$and $\mathrm{PA}^{+}$with ILs are the driving forces for extraction of PABA into IL phase. It is remarkable that the extraction of PABA into the studied ILs is in the order of $\left[\mathrm{C}_{8} \mathrm{mim}\right]\left[\mathrm{BF}_{4}\right]>\left[\mathrm{C}_{4} \mathrm{mim}\right]\left[\mathrm{PF}_{6}\right]>\left[\mathrm{C}_{8} \mathrm{mim}\right]\left[\mathrm{PF}_{6}\right]$, which is in agreement with the order of water content of ILs as was mentioned previously. Furthermore, higher ability of $\mathrm{BF}_{4}^{-}$ than $\mathrm{PF}_{6}{ }^{-}$for $\mathrm{H}$-bond formation with $-\mathrm{COOH}$ and $-\mathrm{NH}_{2}$ groups ${ }^{35}$ of PABA could be another reason for higher extraction of PABA into $\left[\mathrm{C}_{8} \mathrm{mim}\right]\left[\mathrm{BF}_{4}\right]$.

Thus hydrophobicity and electrostatic interactions of solutes with ILs are two driving forces for their partitioning into IL phase. It seems that the effect of hydrophobicity is more significant than that of the electrostatic interactions, because an ionic molecule despite of having ability for elec- 


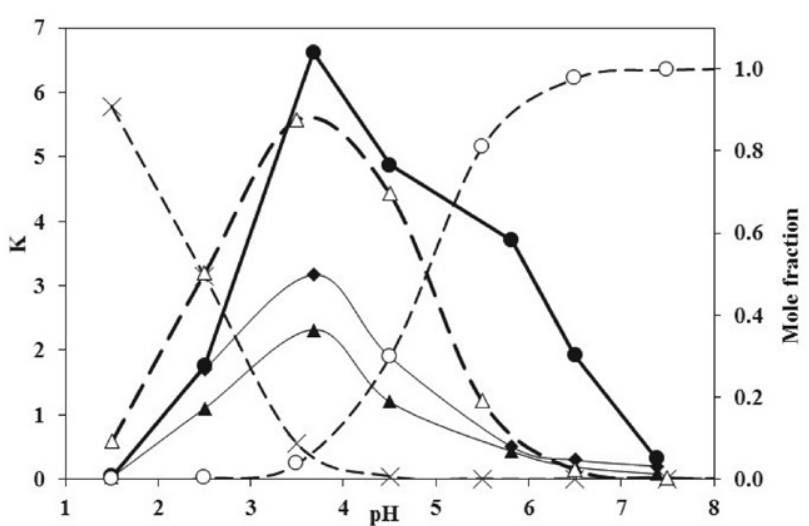

Figure 2. Partition coefficients $(\mathrm{K})$ of PABA between water and different ionic liquids: $(\boldsymbol{\Delta}),\left[\mathrm{C}_{8} \mathrm{mim}\right]\left[\mathrm{PF}_{6}\right] ;(\bullet),\left[\mathrm{C}_{4} \mathrm{mim}\right]\left[\mathrm{PF}_{6}\right] ;(\bullet)$ $\left[\mathrm{C}_{8} \mathrm{mim}\right]\left[\mathrm{BF}_{4}\right]$. Mole fraction of various chemical forms of PABA at different $\mathrm{pH}$ values: $(\mathrm{X})$, cationic form $\left(\mathrm{PA}^{+}\right) ;(\Delta)$, neutral form $(\mathrm{PA}) ;(\mathrm{O})$, anionic form $\left(\mathrm{PA}^{-}\right)$.

trostatic interactions with ILs, is less hydrophobic than a neutral molecule and its extraction into IL phase is lower.

The partitioning behaviors of either glycine (Figure 1) or PABA (Figure 2) were found to follow a similar pattern in all the studied ILs as is demonstrated by their corresponding curves. This indicates that each of the studied ILs can be utilized for investigating the partitioning behavior of a target amphoteric compound such as glycine and PABA in order to specify either its zwitterionic or non-zwitterionic structures.

It is noticeable that according to previous reports, an ion-exchange mechanism could be proposed for extraction of ionic forms of amphoteric compounds into IL phase. ${ }^{30,34}$ So extracted ionic forms of glycine or PABA into IL phase could be as $\left[\mathrm{RNH}_{3}\right]^{+}\left[\mathrm{BF}_{4}\right]^{-},\left[\mathrm{RNH}_{3}\right]^{+}\left[\mathrm{PF}_{6}\right]^{-}$ or $[\mathrm{Rmim}]^{+}\left[\mathrm{RCO}_{2}\right]^{-}$forms.

\section{Conclusion}

Partitioning behaviors of glycine and $p$-amino benzoic acid, as two model substances for amphoteric compounds, into imidazolium-based ILs $\left[\mathrm{C}_{8} \mathrm{mim}\right]\left[\mathrm{BF}_{4}\right]$, $\left[\mathrm{C}_{4} \mathrm{mim}\right]\left[\mathrm{PF}_{6}\right]$, and $\left[\mathrm{C}_{8} \mathrm{mim}\right]\left[\mathrm{PF}_{6}\right]$ was studied. The $\mathrm{pH}$-dependent partition coefficients of both compounds revealed the zwitterionic structures of glycine and non-zwitterionic (neutral) structure of $p$-amino benzoic acid in their isoelectric points. Specification of zwitterionic or non-zwitterionic structures of amphoteric compounds through their partitioning between water and IL phases was found to be a simple, fast and reliable method in comparison to the past reported procedures.

\section{Acknowledgments}

The authors are grateful to Shiraz University Research Council for financial support of this project.

\section{References}

1. Z. Yang, Q. Li, G. Yang, Future Med. Chem. 2016, 8, 2245-2262 DOI:10.4155/fmc-2016-0176

2. R. Marchese, R. Gandori, P. Carloni, S. Raugei, PLoS Comput. Biol. 2010, 6, 1-11. DOI:10.1371/journal.pcbi.1000775

3. T. Wyttenbach, M. Witt, M. T. Bowers, J. Am. Chem. Soc. 2000, 122, 3458-3464. DOI:10.1021/ja992546v

4. W. D. Price, R. A. Jockusch, E. R. Williams, J. Am. Chem. Soc. 1997, 119, 11988-11989. DOI:10.1021/ja9711627

5. R. Wu, T. B. McMahon, Can. J. Chem. 2005, 83, 1978-1993. DOI:10.1139/v05-205

6. R. Wu, T. B. McMahon, J. Am. Chem. 2007, 129, 4864-4865. DOI: $10.1021 /$ ja068715a

7. R. WuTerry, B. McMahon, J. Am. Chem. 2008, 130, 30653078. DOI: $10.1021 /$ ja076685l

8. R. Wu, R. A. Marta, J. K. Martens, K. R. Eldridge, T. B. McMahon, J. Am. Soc. Mass Spectrom. 2011, 22, 1651-1659.

DOI:10.1007/s13361-011-0178-9

9. E.Q. Adams, J. Am. Chem. Soc. 1916, 38, 1503-1510. DOI:10.1021/ja02265a008

10. L. Michaelis, Hydrogen ion concentration, second ed. London, 1926.

11. L. J. Harris, Biochem. J. 1930, 24, 1080-1097. DOI:10.1042/bj0241080

12. C. Bretti, O. Giuffrè, G. Lando, S. Sammartano, SpringerPlus, 2016, 5, 928-949. DOI:10.1186/s40064-016-2568-8

13. I. M. Klotz, D. M. Gruen, J. Am. Chem. Soc. 1945, 67, 843846. DOI:10.1021/ja01221a044

14. P. H. Bell, R. O. Robin, J. Am. Chem. Soc.1942, 64, 2905-2917. DOI:10.1021/ja01264a055

15. K. Venkateswaran, J. M. Stadlbauer, Z. Wu, H. A. Gillis and D. C. Walker, J. Phys. Chem. 1996, 100, 3569-3572.

DOI:10.1021/jp9518320

16. T. Walton, Chem. Rev. 1999, 99, 2071-2084. DOI: $10.1021 /$ cr980032t

17. M. Koel, Ionic liquids in chemical analysis. Taylor \& Francis, Boca Raton, London New York, 2009.

DOI:10.1201/9781420046472

18. J. L. Anderson, J. Ding, T. Welton, D.W. Armstrong, J. Am. Chem. Soc. 2002, 124, 14247-14254.

DOI:10.1021/ja028156h

19. L. Kong, Q. Chen, X. Shen, G. Zhu, J. Zhu, J. Colloid. Interface Sci. 2018, 532, 261-271. DOI:10.1016/j.jcis.2018.07.135

20. S. Chauque, F.Y. Oliva, O. R. Cámara, R. M. Torresi, J. Solid State Electrochem. 2018, 22, 3589-3596.

DOI:10.1007/s10008-018-4078-9

21. V. M. Ortiz-Martínez, A. Ortiz, V. Fernández-Stefanutoc, E. Tojo, M. Colpaert, B. Améduri, I. Ortiz, Polymer 2019, 19, 121583-121593. DOI:10.1016/j.polymer.2019.121583

22. H. Jia, R. Kloepsch, X. He, M. Evertz, S. Nowak, J. Li, M. Winter, T. Placke, Acta Chim. Slov. 2016, 63, 470-483.

DOI:10.17344/acsi.2016.2243

23. E. Weiss, B. Dutta, A. Kirschning, R. Abu-Reziq, Chem. Mater. 2014, 26, 4781-4787. DOI:10.1021/cm501840d

24. L. Sheikhian, S. Bina, J. Chromatogr. B 2016, 1008, 34-43. 
DOI:10.1016/j.jchromb.2015.11.047

25. W. Fam, J. Mansouri, H. Li, J. Hou, V. Chen, Ind. Eng. Chem. Res. 2019, 58, 3304-3313. DOI:10.1021/acs.iecr.8b05027

26. M. Rzelewska-Piekut, M. Regel-Rosocka, Sep. Purif. Technol. 2019, 212, 791-801. DOI:10.1016/j.seppur.2018.11.091

27. G. Absalan, M. Akhond, L. Sheikhian, Talanta 2008, 77, 407411. DOI:10.1016/j.talanta.2008.06.049

28. S. Carda-Broch, A. Berthod, D. W. Armstrong, Anal. Bioanal. Chem. 2003, 375, 191-199.

DOI:10.1007/s00216-002-1684-1

29. P. Bonhote, A. P. Dias, N. Papageorgion, K. Kalyanasundaram, M. Gratzel, Inorg. Chem. 1996, 35, 1168-1178.

DOI:10.1021/ic951325x

30. J. Wang, Y. Pei, Y. Zhao, Z. Hu, Green Chem. 2005, 7, 196-202. DOI: $10.1039 / b 415842 c$

31. J. G. Huddleston, A. E. Visser, W. M. Reichert, H. D. W. G. A. Brokers, R.D. Rogers, Green Chem. 2001, 3, 156-164. DOI:10.1039/b103275p

32. J. D. Holbrey, K. R. Seddon, J. Chem. Soc. Dalton Trans. 1999, 2133-2139. DOI:10.1039/a902818h
33. S. W. Sun, Y. C. Lin, Y. M. Weng, M. J. Chen, J. Food Compos. Anal. 2006, 19, 112-117. DOI:10.1016/j.jfca.2005.04.006

34. G. Absalan, M. Akhond, L. Sheikhian, Amino Acids 2010, 39, 167-174. DOI:10.1007/s00726-009-0391-z

35. H. Tsunekawa, A. Narumi, M. Sano, A. Hiwara, M. Fujita, H. Yokoyama, J. Phys. Chem. B 2003, 107, 10962-10966. DOI:10.1021/jp0300546

36. A. Noda, K. Hayamizu, M. Watanabe, J. Phys. Chem. B, 2001, 105, 4603-4610. DOI:10.1021/jp004132q

37. L. Cammarata, S. G. Kazarian, P. A. Salter, T. Welton, Phys. Chem. Chem. Phys. 2001, 3, 5192-5200.

DOI:10.1039/b106900d

38. V. V. Yaminsky, E. A. Vogler, Current Opinion in Colloid and Interface Science, 2001, 6(4), 342-349.

DOI:10.1016/S1359-0294(01)00104-2

39. H. Shekaari, F. Jebali, Fluid Phase Equilibr. 2010, 295, 68-75. DOI:10.1016/j.fluid.2010.04.002

40. M. G. Freire, L. M. N. B. F. Santos, A. M. Fernandes, J. A. P. Coutinho, I. M. Marrucho, Fluid Phase Equilibr. 2007, 26, 449-454. DOI:10.1016/j.fluid.2007.07.033

\section{Povzetek}

Študirali smo porazdelitvene koeficienta glicina in $p$-amino benzojske kisline, dveh modelnih amfoternih spojin, $\mathrm{v}$ ionske tekočine (IL) na osnovi imidazola, to so $\left[\mathrm{C}_{8} \mathrm{mim}\right]\left[\mathrm{BF}_{4}\right],\left[\mathrm{C}_{4} \mathrm{mim}\right]\left[\mathrm{PF}_{6}\right]$, and $\left[\mathrm{C}_{8} \mathrm{mim}\right]\left[\mathrm{PF}_{6}\right]$. Porazdelitveni koeficienti so pokazali, da ima glicin dvoionsko (zwitterionsko) strukturo, medtem ko ima $p$-amino benzojska kislina nevtralno (ne-zwitterionsko) strukturo v izoelektrični točki. Pokazali smo, da je določitev dvoionske ali neionske strukture amfoternih snovi na osnovi njihovega porazdeljevanja med vodno in IL fazo, enstavna, hitra in zanesljiva metoda v primerjavi $\mathrm{z}$ metodami, o katerih so poročali v preteklosti.

Except when otherwise noted, articles in this journal are published under the terms and conditions of the Creative Commons Attribution 4.0 International License 